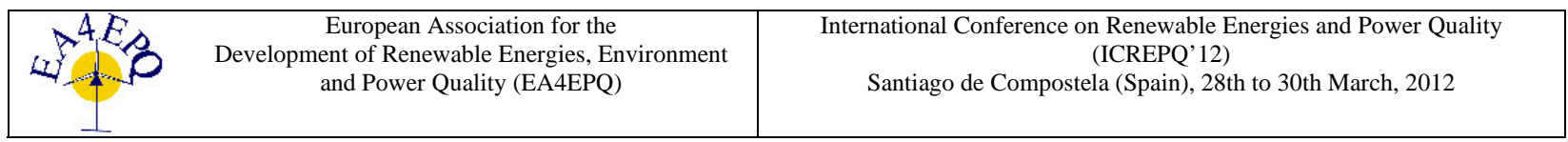

\title{
Renewable energy sources - a promising opportunity for remote mine sites?
}

\author{
J. Paraszczak and K. Fytas \\ ${ }^{1}$ Department of Mining, Metallurgical and Materials Engineering \\ Université Laval \\ 1065, Avenue de la Médecine, Quebec City, G1V 0A6 (Canada) \\ Phone/Fax number:+001 418656 5103, e-mail: jacek.paraszczak@gmn.ulaval.ca, kostas.fytas@gmn.ulaval.ca
}

\begin{abstract}
Mining industry is a substantial consumer of the energy indispensable to power mining and mineral processing equipment and processes. As more and more mine operations move to remote locations, the access to reliable, secure and environment friendly energy sources becomes a key concern. At present, a great majority of remote mines relies heavily on diesel fuel that has to be transported over long distances. In this context, some of the renewable energy sources such as for example wind power or solar energy seem to provide potentially interesting and viable alternatives. Mine operations however, have a very particular character, much different from other industries and from other potential applications of renewable power sources. This paper presents operational conditions of some mining operations, particularly those in remote regions, in the context of their energy needs. The authors analyse current and future capacities to decrease a reliance of remote mines on conventional fuels and energy. The paper analyses and discusses also the conditions to be met by alternative energy sources so that they might become a viable alternative for remote mining operations.
\end{abstract}

\section{Key words}

Mining, remote locations, energy needs, renewable energy sources, trends.

\section{Introduction}

Contrary to manufacturing industry, where one can build a factory in a convenient location, mining companies have no choice: mines must be localized exactly where the deposits of mineral resources (metals, industrial minerals, etc.) are found. As the mineral deposits situated in easily accessible places are rapidly getting depleted, and the world's demand for metals and minerals steadily increases, mining operations move constantly to more and more remote locations. These include the regions such as for example Canadian Far North, deserts in Africa, Asia or Australia, tropical forests or mountain zones in Africa or South America, etc. Remoteness of mine sites usually implies problems related to the accessibility of power sources and limited or no connection to existing transportation infrastructure (roads, railways, waterways, etc.). In such conditions, diesel fuel is basically the only feasible option: it powers mobile equipment's internal combustion engines (ICE) and electric power generators. Therefore, energy cost in these locations accounts for a significant percentage of the overall mining cost.

In this context, renewable energy sources may become an interesting alternative for the companies operating mines in remote regions. This paper will briefly present working conditions and energy requirements of modern mines and it will assess current and future possibilities to use alternative, renewable sources of energy at remote mine sites. Some possible developments for near future will also be discussed.

\section{Energy demands of mines and mineral processing plants}

Mining and mineral processing involve several energy intensive processes. Open-pit mining involves operations such as drilling, blasting, excavating, waste rock handling, ore transportation, pit dewatering and support activities. Underground mining also involves ventilation, primary crushing, hoisting and backfilling. Beneficiation and processing consist of all the processes and operations intended to concentrate or extract valuable material from the ore. It includes: crushing, grinding, separation, and others, depending on the commodity. Obviously, all these 
operations and processes require considerable amounts of energy. Atop of that, each mine must have its infrastructure including workshops (with their own significant energy needs), offices, assay laboratories, storages and depots, guardhouses, etc., that need to be lighted and, in many cases heated or air-conditioned. All these make of mines and concentrators significant energy consumers. In 2002, the cost of energy in the US mining industry was $\$ 3.2$ billion and constituted $21 \%$ of the total cost of supplies [1]. One of the indices of energy intensity is its specific consumption. In mining and mineral processing it is usually expressed in kilowatt hour per tonne $(\mathrm{kWh} / \mathrm{t})$, or kilowatt hour equivalent per tonne $\left(\mathrm{kWh}_{\mathrm{E}} / \mathrm{t}\right)$ of ore mined or milled respectively. The latter accounts for all types of energy consumed using conversion factors. Average energy consumption in the mines in United States has been estimated at $100 \mathrm{kWh}_{\mathrm{E}} / \mathrm{t}$ [1]. This index however may vary considerably due to a number of factors including geology, mining method, equipment selection, economies of scale, ore composition and customer requirements. In what concerns mining operations, specific energy consumption for waste removal, ore excavation, mine dewatering and mine support in open-pit mines in Canada has been between 12 and 13.6 $\mathrm{kWh}_{\mathrm{E}} / \mathrm{t}$ of waste and ore combined [2],[3]. For ore excavation alone, the average number is $4.3 \mathrm{kWh}_{\mathrm{E}} / \mathrm{t}$ of ore [2]. A similar number (3 - $5 \mathrm{kWh} / \mathrm{t}$ of ore excavated) has been reported for Australian copper mines [4]. In underground mines, where all the ore must be hoisted or hauled to the surface, the mine must be ventilated, and the volume of production is significantly lower, mining is by far more energy intensive. Specific energy consumption in Australian underground copper mines is $12-40 \mathrm{kWh}_{\mathrm{E}} / \mathrm{t}$ [4]. In Canadian underground base metal and gold mines specific energy consumption ranged between 58 and 143 $\mathrm{kWh}_{\mathrm{E}} / \mathrm{t}$ mined [3],[5],[6]. It is estimated that a Canadian base metal operation producing one million tonnes a year on a 24/7 schedule has an average power demand of 21 MW, which translates into annual energy consumption of roughly $180 \mathrm{GWh}$ [6].

Mineral processing or concentration is also energy intensive. A study done on a sample of 7 Canadian openpit mines shows an average of $21 \mathrm{kWh}_{\mathrm{E}} /$ tonne of ore milled [2]. Copper processing in Australian open-pit copper mines requires between $15-24 \mathrm{kWh}_{\mathrm{E}} / \mathrm{t}$ [4]. Energy consumption for processing ore coming from underground mines is even higher. In Australian copper operations it is estimated at $24-34 \mathrm{kWh} / \mathrm{t}$ [4]. Following the latter source, comminution (crushing and grinding) accounts for $72 \%$ of this consumption. Mineral processing for the case of Canadian underground mines base metal and gold mines requires $31-100 \mathrm{kWh}_{\mathrm{E}} / \mathrm{t}$ and $39-70 \mathrm{kWh}_{\mathrm{E}} / \mathrm{t}$ respectively [5]. Following Millar et al. [6], for underground mines the numbers are $81 \mathrm{kWh}_{\mathrm{E}} / \mathrm{t}$ milled for base metal processing, and $100 \mathrm{kWh}_{\mathrm{E}} / \mathrm{t}$ for gold processing.

Such energy demands not only involve a significant cost, but they also constitute a serious challenge for the mines located in remote and isolated regions. Specificity of such operations will be presented more in detail in the following section.

\section{Current context of mining in remote areas with regards to energy needs}

Responding to the increasing world demand for metals and minerals, mining companies operate more and more sites located in remote regions. Several mines are in operation or will open soon in Northern Canada, subSaharan Africa, in South American, Australian or Asian desert zones, in tropical areas of Africa and South America, and in other remote and hardly accessible areas. Mining and mineral processing at such locations is very challenging. The section that follows gives an overview of operating conditions at remote mine sites.

\section{A. General characteristics of remote mine sites}

Typical characteristics of these sites are as follows:

- Often harsh climate (hot or cold) with extreme meteorological conditions;

- In most cases good access to land;

- Usually no access to electric-power grid;

- Sometimes restricted land access (for example only through a winter road);

- $\quad$ Limited mine life (from 5 up to even 40 years, depending on reserves and economic factors);

- In many cases limited access to water;

- Presence of dust, humidity or snow (depending on climate conditions);

- $\quad$ Limited access to labour and specialist skills.

One of the most critical problems is availability of electric energy. As the majority of remote mines cannot be connected to any electric power grid, all the electricity required on site must be generated burning diesel fuel. As many operations do not have any access to pipelines, railways, or navigable waterways, combustible must be transported by tanker trucks, further contributing to its consumption. Remoteness of the mine sites has also other repercussions. Since there is usually no local man-labour available, mine personnel works on a so-called "fly-in fly-out" principle, which requires maintaining a whole mining camp including lodging facilities, leisure space, kitchens, gyms, etc. In extreme climate conditions, such as in Canadian North, or in desert regions, these facilities require either very intense heating or air-conditioning. Running and maintaining a whole mining camp involves additional energy consumption atop of that already indispensable to run "conventional” mine infrastructure, and further aggravates energy-related problems for mine operators. All these factors affect adversely production cost and competitiveness of the whole operation.

Principal types of energy consumed at remote sites are:

- Diesel fuel (predominantly for handling and transportation of ore and waste);

- Electricity (the most often provided by diesel generators), and,

- $\quad$ Heat (for thermal processing).

The characteristics of electric demand are the following [4]:

- $\quad$ Peak demand: 5 - 650 (!) MW;

- $\quad$ Fluctuating demand - peak during day; 
- High reliability required (auxiliary back-up is essentially indispensable).

In order to illustrate the nature and scale of energy consumption at remote mine sites, we will present an example of a diamond mine situated in Northern Canada that will soon get in operation.

B. Energy consumption at the remote mine site based on the example of a diamond mine

The analyzed mine is accessible by air and by a stretch of a couple hundred kilometres all season dirt road, and has no access to electric power grid. Mine life is scheduled to be 15 years. At the beginning, the mine will operate as an open-pit, but gradually it will convert to underground operation. For the purpose of the analysis we will focus on years $2-5$. The year 2 marks the actual beginning of production from an open-pit, and in the year 5 the mine will achieve its full production capacity that will be subsequently maintained for the rest of its life. Concentrator comes into operation in the year 3, but it will reach its full capacity the year after. Table 1 below shows the production scheduled for the analyzed period.

Table 1: Ore and waste excavation targets for years $2-5$

\begin{tabular}{|c|c|c|c|c|c|}
\hline Year & \multicolumn{2}{|c|}{$\begin{array}{c}\text { Open-pit } \\
\text { '000 tonnes }\end{array}$} & \multicolumn{2}{c|}{$\begin{array}{c}\text { Underground } \\
\text { '000 tonnes }\end{array}$} & $\begin{array}{c}\text { Total } \\
\text { ore } \\
\text { '000 } \\
\text { tonnes }\end{array}$ \\
\hline & Ore & Waste & Ore & Waste & \\
\hline 2 & 192 & 2766 & - & 220 & 192 \\
\hline 3 & 1237 & 4745 & 51 & 282 & 1288 \\
\hline 4 & 606 & 1158 & 463 & 273 & 1069 \\
\hline 5 & - & - & 2160 & 164 & 2160 \\
\hline
\end{tabular}

Electric power consumption will increase alongside with production volume to reach its maximum in the year 5 . Four sectors of energy consumption are distinguished: open-pit mining, underground mining, concentration and site infrastructure. Table 2 shows power consumption for the analysed period.

Table 2: Energy consumption per category in GWh per year

\begin{tabular}{|c|c|c|c|c|c|}
\hline Year & OP & UG & Concentr. & Infrastr. & Total \\
\hline 2 & 0.8 & $2.5^{1)}$ & 0 & 10 & 13.3 \\
\hline 3 & 0.8 & 3.8 & 8.0 & 10 & 22.6 \\
\hline 4 & 0.6 & 8.5 & 50.2 & 10 & 69.3 \\
\hline 5 & - & 27 & 49 & 10 & 86 \\
\hline
\end{tabular}

OP - open-pit mining; UG - underground mining;

${ }^{1)}$ No actual production from the underground mine at this stage.

It should be stressed that the above table presents exclusively electric energy consumption, and it does not show any equivalent of diesel fuel burnt by mobile dieselpowered mining equipment. Please note also, that although no ore will be produced from the underground part of the mine in the year 2, substantial quantity of energy is indispensable to perform development works, provide ventilation, assure dewatering and maintain safe working conditions. As it may be seen from the table 2, after reaching the targeted level of production, the concentrator will account for about $57 \%$ of all the electric energy consumed on the site.
Based on the numbers shown in the tables 1 and 2, it is possible to estimate specific electric energy consumption. At the stage when the mine and the concentrator achieve full capacity, it will be about $22.7 \mathrm{kWh} / \mathrm{t}$ of ore milled. At this point it should be stressed that processing of diamond ore compared to that of base metals and gold is much simpler and does not require substantial quantities of heat, so it is far less energy intensive.

Meeting the above mentioned energy demand requires considerable installed power. Table 3 below gives simultaneous and average power loads that must be delivered by generator sets.

Table 3: Loads of generator sets by sector of activities

\begin{tabular}{|c|c|c|}
\hline & $\begin{array}{c}\text { Simultaneous } \\
\text { load, kW }\end{array}$ & $\begin{array}{c}\text { Average load, } \\
\mathrm{kW}\end{array}$ \\
\hline $\begin{array}{c}\text { Open-pit } \\
\text { (pumping only) }\end{array}$ & $353(2.6 \%)$ & $88(0.9 \%)$ \\
\hline $\begin{array}{c}\text { Underground } \\
\text { mine }\end{array}$ & $6265(46.2 \%)$ & $2878(30.3 \%)$ \\
\hline Concentrator & $5677(41.9 \%)$ & $5395(56.8 \%)$ \\
\hline $\begin{array}{c}\text { Site } \\
\text { infrastructure }\end{array}$ & $1265(9.3 \%)$ & $1139(12.0 \%)$ \\
\hline $\begin{array}{c}\text { Total generator } \\
\text { sets load }\end{array}$ & 13560 & 9500 \\
\hline
\end{tabular}

For these loads at full production capacity of the mine and the processing plant, generator sets will consume about 24 million litres of diesel fuel per year. This does not include combustible burnt by mobile, diesel-powered equipment. The latter requires further 2 million litres per year, bringing the annual diesel fuel consumption up to 26 million litres. If we convert the energy contained in this quantity of fuel into kilowatt hour equivalent using a ratio of $10.74 \mathrm{kWh} /$ litre [2],[5], we will obtain a specific energy consumption of $130 \mathrm{kWh}_{\mathrm{E}} / \mathrm{t}$ of ore milled. It should be stressed that with no pipeline in the vicinity, all diesel fuel must be delivered by tanker trucks. In the harsh Nordic climate, supplies may be disrupted by snow storms or fog. It goes without saying that trucking of diesel fuel affects adversely operational cost. To make things worse, increasing fuel prices, steadily more stringent regulations for diesel emissions and energy intermittencies are costing dearly to mining companies cutting deep into profits and balance sheets.

This example illustrates the scale of energy needs for a remote mine site. As mentioned before, in the case of base metal or gold operations, more specific energy consumption for a similar volume of ore produced will likely be required, so the stakes are even higher. In the opinion of the authors, energy needs at the sites located in a cold, sub-Arctic climate exceed those in moderate or hot climate. In such circumstances, renewable energy sources deserve to be studied and analysed as a potential alternative to diesel fuel, particularly if they can offer cost savings. This subject will be discussed in the next section. 


\section{Overview of potentially interesting renewable energy sources with regard to mines' needs and working environment}

Providing energy to mining operations in remote locations is very expensive and price fluctuations of fuel oil can easily jeopardize company's profit and lead, in extreme cases, to the suspension of mine activities or even to mine closure. However, any potential alternative energy source should meet at least some of the criteria and conditions relative to this type of industrial activities. As many processes, particularly in mineral processing, are continuous and should not be interrupted, energy supply should be consistent and reliable over time regardless geographical location, climate and weather, time of the day and others. Every energy shortage affects production rate and causes substantial losses. This also means that back-up systems are essentially indispensable.

Many mining operations are located in the developing countries where reliable electricity supply is no longer guaranteed since their growth is faster than their power capacity. As an example, in South Africa since 2008 there have been on-going electrical shortages that expect to last in the foreseeable future forcing mining operations to shut down for days at a time.

As mentioned before, for most of remote off-grid mines in Canada and around the world the most frequently used option for power supply is diesel generation. However, this option is expensive, noisy and generates greenhouse gases which translate to a high carbon footprint. In a typical Canadian mine operating in the remote Canadian North diesel generated electricity costs $30 \% / \mathrm{kWh}$ and more. Diesel fuel costs can vary from country to country, but diesel generated electricity can cost in the range of 50 to $100 \mathrm{\$} / \mathrm{kWh}$ [7]. Recently, with the increasing fossil fuel prices around the world more and more mining companies are looking into renewable energy solutions. These solutions did not receive a lot of attention in the past due to their high cost and doubtful reliability. However, recent technological advances are changing the attractiveness of renewable energy sources. The most frequently sought after renewable energy alternatives for electricity generation in remote areas are solar and wind power.

In terms of initial investment, diesel generators are cheaper but on the other hand operating cost of electricity generation over the life of the mine is dominated by diesel fuel costs. However, although initial capital investment required for solar power or wind turbine systems are much higher, operating costs are much lower since both sun and wind energy comes basically for free.

Concerning photovoltaic power plants, Nougrigat et al. [8] state that a $2000 \mathrm{MW}$ plant having the efficiency of $13 \%$ and able to produce annually 2.8 TWh would cost 4 billion Euros. It would occupy $50 \mathrm{~km}^{2}$ and its projected life would be 30 years. $2000 \mathrm{MW}$ is far too much even for the most energy intensive mines, so for a much smaller plant the scale effects would have to be taken into thorough consideration.
Some mines have already built the first concentrating photovoltaic (CPV) parks. Chevron Mining's molybdenum mine in Questa, New Mexico, USA has installed a field of 173 concentrating photovoltaic trackers onto a mine tailings area generating $1 \mathrm{MW}$ of electricity at peak output [9]. Across the planet there are many thousands of mine tailings areas related to active, inactive or abandoned mine operations. These waste disposal sites correspond to large areas (hundreds of hectares) that are not only of no use to anybody but they also constitute a liability for the mining companies who own them. They could be converted into an important asset where renewable energy systems can be installed to produce carbon-free clean electricity [10].

More than a dozen solar installations are planned in the Atacama desert in Chile to produce electricity for the big copper mines of the area. The Atacama desert receives up to $9.28 \mathrm{kWh}$ of sun power per square meter each day, nearly double what Las Vegas gets. Solar companies claim that due to the strength of the sunshine they could provide the region's dozen or so large mines and hundreds of smaller ones with electricity at prices rivalling energy from plants that burn fossil fuels. A Spanish energy developer Solarpack Corp. Tecnologica is opening a 1-MW plant at a mine owned by Codelco, the Chilean state-owned copper mining company. They claim to be able to sell electricity to mine companies for $10 \pitchfork$ to $14 \mathbb{\$} / \mathrm{kWh}$ with no subsidies as opposed to $12 \$ / k W h$ that Chilean utilities currently sell on the spot market. Solar energy developers see a strong market for their electricity among the Atacama's power-hungry mines, which typically require anywhere from 10 to 400 MW of power. More than $80 \%$ of the electricity in northern Chile is used by the copper mining operations [11].

Many of the world's remote mining operations are located in a region on both sides of the equator between the $35^{\circ}$ latitude North and South parallels where the sun is most intense and reliable (ex. in the sub-Saharan Africa, Australia or Northern Chile) making them ideal for solar power electricity generation. However, even in Northern off-grid remote mining areas solar energy can be used as a supplemental source of electricity generation. A fact typically overlooked is that most solar cells lose efficiency as the temperature rises. Common silicon solar cells lose $7-15 \%$ of their power output for every 10 degrees Celsius rise in ambient temperature above their nominal temperature which is often specified as 20 or 25 degrees $\mathrm{C}$. This means that PV systems are better suited to climates that are cold and sunny [12].

Kim Trapani, a researcher from Laurentian University in Sudbury, Canada has demonstrated the potential of floating solar panels on the McFaulds Lake in a remote part mining area of the Hudson Bay Lowlands that is located off the electric power grid and with no road access. Trapani has estimated that the total installed solar capacity could be of $400 \mathrm{MW}$ capable of supplementing diesel produced electricity to about 16 mines in this 
remote area and enabling them to save a lot of money over a 20 year horizon [12].

Solarmax Thermospastics Racking System (STRS) from Arizona has developed a special system integrating plastic or polymer frames fusion welded onto a thermoplastic liner. These liners can be used to cover tailings areas in order to produce solar power. They are currently being tested on mining locations in Arizona and Chile [13].

The above mentioned advantages stemming from the successful implementation of solar power plants should not however be taken for granted for every potential application. Solar panel performance may be adversely affected by the following factors [14]:

- Imperfect solar panel alignment;

- Dust or water vapour in the atmosphere;

- Dust, water or snow on the panels themselves;

- Ageing of solar cells;

- Losses in wiring, inverter, or due to covering protective glass;

- Heating effect of sunlight on cells.

Therefore, in feasibility studies meant to evaluate a potential of photovoltaic solar panels to generate electricity at remote mine sites, one should consider the following [14]:

- $\quad$ Solar incidence at the site;

- Efficiency of the PV modules;

- Cost per watt per square meter;

- Dollar cost of the "balance of system" (BOS): supporting structures, wiring, installation, etc., plus, in the case of large-scale PV power stations, land costs and site works such as levelling, roads, water supply for panel washing, etc.;

- Energy losses imposed by BOS;

- Proportion of energy generated that it takes to build the plant and decommission it at the end of mine life;

- Lifetime assumed for the system.

Wind power is another attractive renewable energy source for electricity generation in remote mining areas. Mining companies have started building wind farms around the world. The best example is MSPL Ltd., one of India's largest iron ore companies. They have built the largest installed wind power generation capacity in India. They have developed seven wind farms generating $175 \mathrm{MW}$ of power that provide all of the company's energy needs. Moreover, they provide the excess power produced to 200,000 homes in nearby communities. They have even started producing wind turbines using their own iron ore to produce the turbines [15].

Since 2010 Barrick Gold has installed a wind turbine at its Veladero mine up on the Chile-Argentina border. It has been recognized by Guinness World Records as the highest altitude wind generator in the world. Located at 4,110 meters above sea level in the Andes Mountains, the $2 \mathrm{MW}$ and $\$ 8.5$ million wind turbine supplies up to 20 per cent of the total electricity needed to power Veladero mine operations. The turbine was the first of its kind to be tested to endure extreme cold, heavy snowfall and high winds, which top 222 kilometres per hour [16]. Also recently, Barrick Gold inaugurated in northern Chile the Punta Colorada Wind Farm, the largest wind farm ever built by a mining company in the country. This large-scale \$50 million project, located in the town of La Higuera in the Coquimbo Region of Northern Chile, consists of 10 wind turbines that generate 20 megawatts of power, enough to supply the energy needs of 10,000 families [17].

Rio Tinto has recently announced that it will build a wind farm in order to cut diesel fuel consumption for power generation at its Diavik diamond mine $400 \mathrm{~km}$ north of Yellowknife in Northern Canada. It will feature 4 wind turbines totalling 9.2 MW of electricity capacity. It will be the first industrial wind farm in the operating mine in northern Canada [18]. It is expected to cut the mine's diesel consumption by $10 \%$, or 4 million litres, resulting in 100 fewer truckloads travelling along the winter road. The company expects its greenhouse gas emissions will drop by $6 \%$, or 12,000 tonnes.

The El Toqui zinc underground mine located in a remote area in southern Chile has recently opted for a hydraulicwind-diesel to generate electricity. [19].The mine is located at the feet of the Andes, in the Aisén region, near the Argentine border. Like many mine sites in South America, El Toqui is isolated from the populated areas and from the national electricity grid where diesel generated electricity is very expensive. Out of a total power consumption of $40.8 \mathrm{GWh}$ last year $38.5 \%$ came from the mine's hydro power (river-run with no water storage capacity), $13.9 \%$ from wind power and the remaining from diesel generation. The wind farm is capable of supplying a maximum of $23 \%$ of the mine's demand. There is a real time monitoring system of the wind farm that minimizes diesel fuel generation and keeping the hydro plant at full capacity. The river's low flow season is typically in the summer, when winds are more stable. The hybrid system has saved significant amounts of diesel fuel so far and the realized carbon credit of 2,600 t $\mathrm{CO}_{2}$ /year will be sold on the carbon credit market. The local community has readily accepted the project since it was a means to extend the mine life.

It is evident that in many secluded regions of the world, wind can make a considerable contribution to energy supply. However, problems of variability, integration, and, in some cases, availability of the space seem likely to limit the contribution to a fraction of what is actually needed to power mine and mineral processing operations. It is important to keep in mind that whatever this fraction is, we can only get it if we have other energy generating plant or back-up system to rely on where there is no wind. So, it is almost indispensable that two redundant power generation plants having similar capacities be built, maintained and, by the end of mine life, decommissioned, only to ensure stable and reliable power supply for the mine and its processing plant. This may have a significant impact on the cost balance sheet.

Geothermal energy can also be used when available to supplement the diesel electricity generation. The most 
interesting example is the Lihir Gold Mine located on the remote Lihir island in the Bismarck Archipelago approximately $800 \mathrm{~km}$ north east of Port Moresby, the capital of Papua New Guinea [20]. The geothermal power plant installed on the youngest volcanic feature of the island is rated at $57 \mathrm{MW}$ and generates $75 \%$ of the mine's power requirements. It is proposed to extend the capacity of the plant so that the entire mine will be run on geothermal power. Before the geothermal plant the mine and the local community used diesel electricity generation alone. In 2007, at US14 a kWh, geothermal power competed well with US12 $₫$ a kilowatt hour fuel generated power. Lihir expects to generate as much as \$US5 million a year from the sale of carbon credits [21].

\section{Conclusions}

Renewable energy alternatives such as solar and wind power for electricity generation in remote mining areas are becoming more and more attractive as fossil fuel prices are increasing. These carbon free technologies could not only help mining companies save money but also to improve their public perception in an era of heightened environmental consciousness. The advantages of these green sustainable technologies are not only to provide an environmental-risk free and modestly reliable power source for mining operations in the developing countries but also to reduce the carbon footprint of mining operations, to earn carbon credits for the mining companies that can be traded or sold and to earn tax credits. Moreover, extra power can be sold back to the grid and generate revenues. And last but not least, they can contribute to improving the public image of mining, adding shareholder value and appealing to environmental conscious investors.

At the same time, other important factors must also be taken into consideration. If we decide to put in place an alternative energy generation plant or installation, all the parts and elements must be delivered to the site and assembled in often extreme conditions. Moreover, no mine has an infinite lifetime and regulations in many countries require mining companies to perform reclamation work and rehabilitate the site. This means that they must not leave in place any infrastructure built for the purpose of mining and processing. Therefore, if there remains no potential consumer of the energy in the region, all equipment and structures used to generate energy must be decommissioned, dismantled and duly removed from the site. All the associated cost and effort may overcast the potential gains over the diesel-fuelled electricity generation. In any study involving discussion over alternative energy sources, these factors must not be forgotten, and their impact underestimated.

\section{References}

[1] "Mining Industry Energy Bandwidth Study", prepared by BCS Inc., US Department of Energy (2007), 43 pp.

[2] "Benchmarking The Energy Consumption of Canadian Openpit mines”, Natural Resources Canada, Ottawa, Canada (2005), 56 pp., ISBN 0-662-39538-7.

[3] T. Albanese and J. McGagh "Future Trends in Mining" [in:] “SME Mining Engineering Handbook, $3^{\text {rd }}$ Edition”, P. Darling
(Editor), Society for Mining, Metallurgy, and Exploration Inc., Littleton, CO, USA (2011), pp. 21-36.

[4] G. Nathan and S. Grano, "Emerging renewable technologies for remote mine sites”, Centre for Energy Technology, University of Adelaide, Australia (2011). Powerpoint presentation:

http://www.innovation.sa.gov.au/_data/assets/pdf_file/0003/19 290/Nov_11__Nathan_Grano_Presentation.pdf, consulted on January 14, 2012.

[5] "Benchmarking The Energy Consumption of Canadian Underground Bulk Mines”. Natural Resources Canada, Ottawa, Canada (2005), 73 pp. ISBN 0-662-39539-5.

[6] D.L. Millar, M. Levesque, G. Lyle and K. Bullock, "Enabling advanced energy management practice for mineral operations”, paper presented at the Annual General Meeting of the Canadian Institute of Mining, Montreal, PQ, Canada, 22-25 May 2011.

[7] R. Sammut, "Remote solar power", International Mining, November 2011, pp. 88.

[8] V. Nougrigat, T. Delpout-Ramat, H. Leroux and M. Valin, "Solaire - une alternative au nucleaire", Science et vie, no. 1125, juin 2011, pp. $56-75$.

[9] T. Woody, "Chevron mines solar energy at tailings dump", April 4, 2011, on Forbes web site: http://www.forbes.com/sites/toddwoody/2011/04/21/chevronmines-solar-energy-at-tailings-dump/, consulted on January 14, 2012.

[10] B. Loftis, "Untapped Resource: converting mine sites into renewable energy assets”, Engineering \& Mining Journal, April 2010, pp.50-56.

[11] S. Nielsen, “A Solar Mother Lode for Chile's Mines”, February 10, 2011, on Business Week web site: http://www.businessweek.com/magazine/content/11_08/b42160 12473761.htm, consulted on January 14, 2012

[12] H. Campbell, "Solar power proposed for remote mines", September 2011, on Sudbury Mining Solutions Journal's web site:

http://sudburyminingsolutions.com/articles/SustainableDevelop ment/09-11-Solar-power.asp, consulted on January 14, 2012

[13] J. Chadwick, “Tailings power”, International Mining, May 2010, pp. 53-54.

[14] T. Trainer, "Renewable Energy Cannot Sustain a Consumer Society”, Springer, Doordrecht, The Netherlands (2007).

[15] M. Ashby, "Is the mining industry ready to go green?", Mining Engineering, November 2008, pp. 33-36.

[16] Barrick Gold, "Veladero wind turbine is one for the record books”, April 15, 2010, on Barrick Gold's web site: http://barrickbeyondborders.com/2010/04/veladero-windturbine-is-one-for-the-record-books/, consulted on January 14, 2012.

[17] Anon., "Barrick completes a 50M\$ wind farm in Chile", Canadian Mining Journal, December 2011, vol. 132, p. 6.

[18] CBC News North, "Diavik mine to build wind turbines", November 4, 2011, on CBC News North web site: http://www.cbc.ca/news/canada/north/story/2011/11/03/northdiavik-wind-farm.html, consulted on January 14, 2012.

[19] N. Gridley and M. Banto, "Hydraulic-wind-diesel hybrid system to operate an underground zinc mine at El Toqui, Chile", Proceedings of ENERMIN 2010 conference, 14-16 November, 2010, Santiago, Chile, pp. 46-47.

[20] Melaku M., Geothermal Development at Lihir - An Overview, Proceedings of World Geothermal Congress 2005, Antalya, Turkey, 24-29 April 2005, pp. 1-4.

[21] B. FitzGerald, "Lihir gold turns green as it bubbles up", April 2007, on Age.Com.Au web site: http://www.theage.com.au/news/business/lihir-gold-turnsgreen-as-it-bubbles-up/2007/04/09/1175971018447.html Consulted on January 16, 2012. 